\title{
Anatoxin-a producing Tychonema (Cyanobacteria) in European waterbodies
}

\author{
S. Shams ${ }^{a, b}$, C. Capelli ${ }^{a, c}$, L. Cerasino $^{a}$, A. Ballot $^{d}$, D.R. Dietrich ${ }^{b}$, \\ K. Sivonen ${ }^{e}$, N. Salmaso ${ }^{a, *}$ \\ ${ }^{a}$ IASMA Research and Innovation Centre, Istituto Agrario di S. Michele all'Adige - Fondazione E. Mach, \\ Via E. Mach 1, 38010 S. Michele all'Adige (Trento), Italy \\ ${ }^{\mathrm{b}}$ Human and Environmental Toxicology Group, Department of Biology, University of Konstanz, P.O. Box X 622, \\ D 78457 Konstanz, Germany \\ ${ }^{c}$ Department of Biology, University of Florence, Via La Pira 4, 50121 Florence, Italy \\ ${ }^{\mathrm{d}}$ Norwegian Institute for Water Research (NIVA), Gaustadalléen 21, NO 0349 Oslo, Norway \\ e Department of Food and Environmental Sciences, Division of Microbiology and Biotechnology, P.O.Box 56, \\ Biocenter 1 Viikki (Viikinkaari 9), FIN 00014, Helsinki University, Finland
}

Keywords:

Anatoxin a

Tychonema

Cell quota

Polyphasic approach

Phylogenetic analysis

European waterbodies
A B S T R A C T

In order to identify the cyanobacterial species responsible of anatoxin a (ATX) production in Lake Garda (Northern Italy), an intensive isolation and culturing of filamentous cyano bacteria were established since 2014 from environmental samples. In this work, we report a detailed account of the strategy adopted, which led to the discovery of a new unexpected producer of ATX, Tychonema bourrellyi. So far, this species is the first documented example of cultured Oscillatoriales able to produce ATX isolated from pelagic freshwater ecosys tems. The isolated filaments were identified adopting a polyphasic approach, which included microscopic species identification, genetic characterisation and phylogenetic analyses based on 16S rRNA genes. The taxonomic identification was further confirmed by the high (>99\%) rbcLX sequence similarities of the T. bourrellyi strains of Lake Garda with those deposited in DNA sequence databases. More than half of the isolates were shown to produce a significant amount of ATX, with cell quota ranging between 0.1 and $2.6 \mu \mathrm{gmm}{ }^{3}$, and 0.01 and $0.35 \mathrm{pg}$ cell ${ }^{1}$. The toxic isolates were tested positive for anaC of the anatoxin a synthetase (ana) gene cluster. These findings were confirmed with the discovery of one ATX producing T. bourrellyi strain isolated in Norway. This strain and a further non ATX producing Norwegian Tychonema bornetii strain tested positive for the presence of the anaF gene of the ana gene cluster. Conversely, none of the Italian and Norwegian Tychonema strains were positive for microcystins (MCs), which was also confirmed by the absence of mcyE PCR products in all the samples analysed. This work suggests that the only reliable strategy to identify cyanotoxins producers should be based on the isolation of strains and their identification with a polyphasic approach associated to a concurrent metabolomic profiling.

\footnotetext{
* Corresponding author. Tel.: +390461 615323.

E mail address: nico.salmaso@fmach.it (N. Salmaso).
} 


\section{Introduction}

The long evolutionary history is the basis of the high competitive ability that characterizes cyanobacteria. They are distributed in most aquatic and terrestrial habitats, including extreme environments (Paerl et al., 2003; Boyer and Zimba, 2007; Kleinteich et al., 2012). In waterbodies characterized by high concentrations of nutrients, limited water exchange and high temperatures and thermal stability, cyanobacteria can develop with high biomasses, giving rise to the formation of blooms at the surface, euphotic zone or in the metalimnic layers, largely depending on the respective species (Paerl and Paul, 2012). Cyanobacteria represent one of the major causes of ecosystem degradation and impairment of the economical value of freshwater resources. Specific strains produce a wide range of powerful toxins, with important implications for health risks associated with the human exploitation of rec reational and drinking waters (Meriluoto and Codd, 2005; Mankiewicz Boczek et al, 2011; Zamyadi et al., 2012). The principal classes of cyanotoxins are microcystins, nodularins, anatoxin $\mathrm{a}$ and homoanatoxin $\mathrm{a}$, anatoxin $\mathrm{a}(\mathrm{S})$, saxitoxins and cylindrospermopsins (Metcalf and Codd, 2012; Méjean et al, 2014).

Compared with microcystin (MC) producers, only a few anatoxin a (ATX) producing taxa have been distinctly isolated and characterized (Table 1). Other reports, based on analyses carried out on bulk environmental samples, suggest the ex istence of a wide spectrum of potential cyanobacterial taxa able to produce ATX (see, among the others, Carrasco et al., 2007; Van Apeldoorn et al., 2007; Aráoz et al., 2010; Metcalf and Codd, 2012; Quiblier et al., 2013). Many reports, however, were not confirmed by analyses made on isolated strains. Toxic species can be detected using direct analytical chemical approaches (Meriluoto and Codd, 2005; Humpage et al., 2012; Metcalf et al, 2012) as well as molecular methods able to detect the presence of toxin biosynthetic genes (Pearson and Neilan, 2008; Sivonen, 2008; Rantala Ylinen et al., 2011a). Nevertheless, until a few years ago, a genetic molecular approach to identify ATX encoding genes was not feasible because of the unknown biosynthetic pathway leading to the production of anatoxin. Biosynthetic genes coding for ATX have been characterized only recently in a benthic Oscillatoria
PCC 6506 (Méjean et al, 2009, 2010) and planktonic Anabaena sp. strain 37 (Rantala Ylinen et al., 2011b), opening the way to the design and use of primers for the detection of genes coding ATX in Oscillatoria, Phormidium, Aphanizomenon and Anabaena strains (Cadel Six et al., 2009; Ballot et al., 2010; Wood et al., 2010; Rantala Ylinen et al., 2011b).

In a recent work, Cerasino and Salmaso (2012) documented a widespread presence of ATX in the lake district south of the Alps. Based on analyses carried out on environmental sam ples collected during the warmer months, detectable con centrations of ATX ranging between 0.1 and $0.6 \mu \mathrm{g} \mathrm{L}{ }^{1}$ were found in the lakes Garda, Iseo, Como and Maggiore, i.e. the largest lakes that experienced a recent colonization and summer surface blooms of Dolichospermum lemmermannii (Salmaso et al., 2012). However, a clear identification of pro ducers in the different seasons was not possible because biological analyses on isolated strains were not available.

Based on the hypothesis that filamentous cyanobacteria could possibly be amongst the ATX producers, cultures of Oscillatoriales were established from environmental samples collected since 2014 in Lake Garda with the aim to isolate potential new producers. Owing to the very low abundance of cyanobacteria usually recorded in the winter months (Salmaso, 2011), samples were collected using plankton nets and initial cultures established. The isolated cyanobacteria were then examined and identified following a polyphasic approach (Vandamme et al., 1996; Lee et al., 2014), which included microscopic species identification, genetic and phylogenetic analyses. Culture strains were further screened for cyanotoxins, particularly ATX and MCs, and tested for the presence of ATX and MCs biosynthesis encoding genes. Above approach led to the discovery and characterization of a new unexpected filamentous cyanobacterial producer of ATX.

\section{Methods}

\subsection{Study site}

Lake Garda is located at the southern border of the north eastern Italian Alps, at $65 \mathrm{~m}$ a.s.l. With a volume of more than $49 \times 10^{9} \mathrm{~m}^{3}$, a maximum depth of $350 \mathrm{~m}$ and a surface of

Table 1 - Cyanobacterial anatoxin-a producers. The list, at the genus level, includes only the results obtained from analyses carried out on isolated strains in culture conditions.

\begin{tabular}{|c|c|c|}
\hline & Genus & Selected references \\
\hline \multirow[t]{4}{*}{ Heterocystous genera } & Dolichospermum/Anabaena & $\begin{array}{l}\text { Sivonen et al. (1989), Lakshmana Rao et al. (2002) and } \\
\text { Rantala Ylinen et al. (2011b) }\end{array}$ \\
\hline & Aphanizomenon & Sivonen et al. (1989) and Osswald et al. (2009) \\
\hline & Cuspidothrix (Aphanizomenon) & $\begin{array}{l}\text { Wood et al. (2007a), Ballot et al. (2010) and } \\
\text { Hodoki et al. (2013) }\end{array}$ \\
\hline & Cylindrospermum & Sivonen et al. (1989) \\
\hline \multirow[t]{3}{*}{ Oscillatoriales } & Oscillatoria $a^{\mathrm{a}}$ & $\begin{array}{l}\text { Sivonen et al. (1989), Edwards et al. (1992), } \\
\text { Aráoz et al. (2005) and Rantala Ylinen et al. (2011b) }\end{array}$ \\
\hline & Phormidium ${ }^{b}$ & Wood et al. (2012) and Harland et al. $(2013,2014)$ \\
\hline & Tychonema & This work \\
\hline
\end{tabular}


$368 \mathrm{~km}^{2}$, Lake Garda is one of the largest freshwater bodies in Europe. From the 1970 s to the 1990 s the average concentra tions of total phosphorus in the whole water column doubled, from 10 to $20 \mu \mathrm{g} \mathrm{L}^{1}$ and beyond. Present concentrations are decreasing and stabilising around $18 \mu \mathrm{g} \mathrm{L}^{1}$. Information on the lake and previous investigations were reported in Salmaso and Mosello (2010).

\subsection{Collection of samples and environmental variables}

The sampling station was located at the deepest point of the lake $(350 \mathrm{~m})$, between the villages of Brenzone and Gargnano $(45.69 \mathrm{~N}, 10.72 \mathrm{E})$. Field measurements and collection of sam ples were made between February and April 2014 (Table 2). Owing to the very low abundance, in February and March 2014 phytoplankton was collected by single vertical tows from 10 to $15 \mathrm{~m}$ to the surface with a $25 \mathrm{~cm}$ diameter $80 \mu \mathrm{m}$ mesh plankton net, which resulted in $0.5-0.7 \mathrm{~m}^{3}$ of filtered water. In April 2014, filamentous cyanobacteria were collected with plankton nets and Niskin bottles. Vertical profiles of water temperature were carried out with a multi parameter probe (Idronaut Ocean Seven 316). The light attenuation coefficients $\left(K_{d}\right)$ were measured with a submersible irradiance sensor, LiCor 192SA. The euphotic depth was computed as $Z_{\text {eu }} \ln (100) \times K_{d}{ }^{1}(K i r k, 1994)$. Concentrations of dissolved inorganic nitrogen (DIN), soluble reactive phosphorus (SRP) and total phosphorus (TP) were carried out using standard methods (APHA et al., 2000; Cerasino and Salmaso, 2012).

\subsection{Isolation of strains, culture conditions and} morphological characterization

Single filaments of cyanobacteria were isolated from diluted net phytoplankton samples under a stereomicroscope (Leica M125) and a macroscope (WILD M420) using a micropipette. The single filaments were washed 3 times and placed in microwell plates containing $3 \mathrm{~mL} \mathrm{Z8}$ medium (Kotai, 1972). After initial growth, as assessed by visual inspection and the macroscope, single strains were first transferred to $30 \mathrm{~mL} \mathrm{Z8}$ medium and, upon successful growth, to $150 \mathrm{~mL}$ medium $\mathrm{Z} 8$

\begin{tabular}{|c|c|c|c|c|c|c|c|}
\hline \multicolumn{2}{|l|}{ Variables } & \multicolumn{2}{|c|}{$11 \mathrm{Feb}$} & \multicolumn{2}{|c|}{11 March } & \multicolumn{2}{|c|}{8 April } \\
\hline Depth & $\mathrm{m}$ & 0 & 20 & 0 & 20 & 0 & 20 \\
\hline Temperature & ${ }^{\circ} \mathrm{C}$ & 9.1 & 9.1 & 10.0 & 9.2 & 12.4 & $\begin{array}{l}9.9 \\
8.2\end{array}$ \\
\hline $\begin{array}{l}\mathrm{pH} \\
\text { Conductivity }\end{array}$ & $\begin{array}{l}\mu \mathrm{S} \mathrm{cm}{ }^{1} \\
\text { at } 20^{\circ} \mathrm{C}\end{array}$ & $\begin{array}{l}7.6 \\
211\end{array}$ & $\begin{array}{l}7.9 \\
214\end{array}$ & $\begin{array}{l}7.7 \\
212\end{array}$ & $\begin{array}{l}8 \\
213\end{array}$ & $\begin{array}{l}8.4 \\
211\end{array}$ & $\begin{array}{l}8.2 \\
214\end{array}$ \\
\hline $\mathrm{NO}_{3} \mathrm{~N}$ & $\mu \mathrm{g} \mathrm{NL}^{1}$ & 273 & 256 & 337 & 341 & 227 & 268 \\
\hline DIN & $\mu \mathrm{g} \mathrm{NL}^{1}$ & 280 & 261 & 342 & 346 & 232 & 275 \\
\hline SRP & $\mu g \mathrm{PL}^{1}$ & 9 & 8 & 3 & 4 & 2 & $<2$ \\
\hline TP & $\mu \mathrm{g} \mathrm{P} \mathrm{L}^{1}$ & 14 & 11 & 10 & 16 & 15 & 12 \\
\hline$K_{d}$ & $\mathrm{~m}^{1}$ & 0.17 & & 0.21 & & 0.19 & \\
\hline$Z_{\text {eu }}$ & $\mathrm{m}$ & 27 & & 22 & & 24 & \\
\hline
\end{tabular}

CELLSTAR (Greiner Bio One $\mathrm{GmbH}$ ) cell culture flasks. The flasks were maintained at $20^{\circ} \mathrm{C}$ under continuous light con ditions $\left(25 \mu \mathrm{mol} \mathrm{m}{ }^{2} \mathrm{~s}^{1}\right)$. From each single culture, after careful homogenization, $15 \mathrm{~mL}$ were preserved with Lugol's solution for biovolume determinations, whereas $250 \mathrm{~mL}$ were filtered with a $0.45 \mu \mathrm{m}$ GF/C filter (Whatman - GE Healthcare Life Sciences) for subsequent cyanotoxin and genetic analyses.

Depending on abundances, cell densities and biovolumes were estimated by measuring cell sizes and length of fila ments from 1 to 3 transects at 200 magnification in $10 \mathrm{~mL}$ sedimentation chambers of $25 \mathrm{~mm}$ diameter. Morphological features were analysed using an inverted microscope (Zeiss Axiovert 135). Single specimens were identified following morphometric and morphological criteria described in Komárek and Albertano (1994) and Komárek and Anagnostidis (2007).

Over 65 single filament cultures were analysed micro scopically, while 24 randomly selected cultures were analysed for the presence of cyanotoxins and for preliminary sequencing of $16 \mathrm{~S}$ rRNA genes with reverse primer. Complete analyses of toxins, cyanotoxins encoding genes, and sequencing of $16 \mathrm{~S}$ rRNA and rbcLX genes (with forward and reverse primers) were carried out in 4 single filament cultures selected randomly from each of the 3 sampling time points (12 isolates).

\subsection{Cyanotoxins analyses}

\subsubsection{Toxin extraction}

To measure intracellular concentrations of toxins, $250 \mathrm{~mL}$ of cyanobacterial cultures were filtered with a $0.45 \mu \mathrm{m}$ GF/C fil ter. The filter was frozen and stored at $20^{\circ} \mathrm{C}$ until further processing (within one week of filtration). For toxin extraction, the filter was homogenized for $5 \mathrm{~min}$ after addition of $7 \mathrm{~mL}$ of extraction solvent ( $70 \%$ methanol containing $0.1 \%$ formic acid) in a homogenization tube. After centrifugation ( $9850 \mathrm{G})$, the supernatant was transferred and the pellet was re extracted again with an additional $7 \mathrm{~mL}$ of extraction solvent. The evolving supernatants were combined. A $2 \mathrm{~mL}$ aliquot of the filter extract was filtered on Phenex RC syringe filter $(0.2 \mu \mathrm{m}$ pore size, Phenomenex) and used for the determination of MCs and nodularin (NOD R) content via liquid chromatogra phy-mass spectrometry (LC-MS). The remaining filter extract was reduced under vacuum and filtered with a $0.2 \mu \mathrm{m}$ pore size RC syringe filter and the filtrate subjected to alkaloid (ATX, and cylindrospermopsin, CYN) LC-MS analytics.

\subsubsection{LC-MS analysis}

LC-MS analyses were carried out on a Waters Acquity UPLC system directly coupled to an AB SCIEX 4000 QTRAP mass spectrometer equipped with a turbo ion spray interface. Standard injection volume was $2 \mu \mathrm{L}$. The analysis of MC and nodularin $\mathrm{R}$ was carried out using a Phenomenex Kinetex XB C18 column $(1.7 \mu \mathrm{m}$ particle size, $2.1 \times 50 \mathrm{~mm})$ at $40^{\circ} \mathrm{C}$. The mobile phase consisted of water (A) and acetonitrile (B), both containing $0.1 \%$ formic acid. A linear gradient scheme was employed: the starting eluent was $80 \% \mathrm{~A}$, decreased to $30 \% \mathrm{~A}$ at $4.5 \mathrm{~min}$, and finally restored at $80 \% \mathrm{~A}$ at $6.5 \mathrm{~min}$ (hold 
$0.5 \mathrm{~min}$ ). The total run time was $7 \mathrm{~min}$ with a flow rate of $0.25 \mathrm{~mL} \mathrm{~min}{ }^{1}$. The analysis of CYN and ATX was carried out using a Phenomenex Kinetex HILC column $(1.7 \mu \mathrm{m}$ particle size, $2.1 \times 50 \mathrm{~mm}$ ) at $30^{\circ} \mathrm{C}$. The mobile phase consisted of water with $1 \%$ acetonitrile (A), containing ammonium acetate $(10 \mathrm{mM})$ and acetic acid $(10 \mathrm{mM})$, and acetonitrile (B). A linear gradient scheme was employed: the starting eluent was $10 \% \mathrm{~A}$ (hold $0.5 \mathrm{~min}$ ), raised to $25 \% \mathrm{~A}$ at $1 \mathrm{~min}$ (hold $1 \mathrm{~min}$ ), raised to $60 \% \mathrm{~A}$ at $3.5 \mathrm{~min}$ (hold $2 \mathrm{~min}$ ), and finally returned to $10 \% \mathrm{~A}$ at $8 \mathrm{~min}$ (hold $2 \mathrm{~min}$ ). The total run time was $10 \mathrm{~min}$ with a flow rate of $0.25 \mathrm{~mL} \mathrm{~min}{ }^{1}$.

The mass detector was operated in positive Electro Spray mode (ESI+) using the Multiple Reaction Monitoring (MRM) scanning mode. General settings were as follows: ion spray voltage $5000 \mathrm{~V}$, entrance potential $10 \mathrm{~V}$, cell exit potential $10 \mathrm{~V}$, interface heater temperature $300^{\circ} \mathrm{C}$. For each target com pound, two transitions were monitored. Toxin identification was achieved by comparing the chromatographic retention time and relative intensity of the two transitions with those of the commercial standards. Toxin quantification was per formed with the external standard procedure, in which, for each compound, a calibration curve was obtained using the most intense transitions. Compound specific settings of the mass detector and performance data of the methods are listed in Table 3.

Homoanatoxin a and other degradation products e.g. dihydro and epoxy homoanatoxin a were not quantified because analytical protocols were still under evaluation.

Microcystins (RR, [D Asp ${ }^{3}$ ] RR, YR, LR, WR, LA, LY, LW, LF), NOD R and CYN analytical standards were purchased from Vinci Biochem, ATX from Tocris Cookson Ltd. All solvents and reagents used in this procedure were LC-MS grade. The limits of quantitation (LOQ) were between 30 and $500 \mathrm{ng} \mathrm{L}^{1}$ (different MCs congeners), $140 \mathrm{ng} \mathrm{L}^{1}$ (NOD R), $30 \mathrm{ng} \mathrm{L}^{1}$ (ATX), and $8 \mathrm{ng} \mathrm{L}{ }^{1}$ (CYN).

\subsection{DNA extraction, PCR amplification and sequencing}

Total genomic DNA was extracted from the filters using the Mo Bio PowerWater ${ }^{(10}$ DNA Isolation Kit (Mo Bio Laboratories, Inc., CA, USA) following manufacturer's instructions. The quantity and quality of DNA was measured by spectropho tometry with a NanoDrop ND 8000 (Thermo Fisher Scientific Inc., MA, USA).

Taxonomic identification and phylogenetic analyses of filamentous cyanobacteria were carried out by the amplifica tion of a short fragment (ca. $420 \mathrm{bp}$ ) of the 16S rRNA gene using the forward primer CYA359F and an equimolar mixture of the reverse primers CYA781Ra and CYA781Rb (Nübel et al., 1997) synthesized commercially (Sigma-Aldrich Co. LLC). The PCRs were carried out on an Eppendorf Mastercycler ep (Eppendorf AG, Hamburg, Germany). The reaction mix, with a final vol ume of $25 \mu$ l, contained $1 \times$ Optimized DyNAzyme PCR Buffer (Thermo Scientific), $0.2 \mathrm{mM}$ dNTPs mix (Thermo Scientific), $0.1 \mu \mathrm{M}$ forward primer, $0.05 \mu \mathrm{M}$ each of the two reverse primers, $1 \mathrm{U}$ of DyNAzyme II DNA Polymerase (Thermo Sci entific), and $1 \mu \mathrm{l}$ of DNA templates. Genomic DNA concentra tions were in the range $4.9-20.3 \mathrm{ng} \mu \mathrm{L}{ }^{1}$. The cycling protocol consisted of a first denaturation step at $94^{\circ} \mathrm{C}$ for $3 \mathrm{~min}$ fol lowed by 35 cycles of DNA denaturation at $94^{\circ} \mathrm{C}$ for $30 \mathrm{~s}$,
Table 3 - Compound-specific parameters in LC-MS analysis of toxins. All toxins are reported in the same table for clarity, but MC/NOD and CYN/ATX are analysed in different chromatographic conditions.

RT chromatographic retention time; DP declustering potential; CE collision energy.

\begin{tabular}{|c|c|c|c|c|c|}
\hline \multirow{2}{*}{$\begin{array}{l}\text { Toxin } \\
\text { variant }\end{array}$} & \multirow[t]{2}{*}{ RT (min) } & \multicolumn{4}{|c|}{ MS acquisition parameters } \\
\hline & & $\begin{array}{c}\text { MRM transitions } \\
{ }^{\mathrm{a}}(\mathrm{m} / \mathrm{z})\end{array}$ & Ratio $^{b}$ & $\begin{array}{l}\text { DP } \\
\text { (V) }\end{array}$ & $\begin{array}{l}\text { CE } \\
\text { (V) }\end{array}$ \\
\hline \multirow[t]{2}{*}{ [D Asp3]RR } & 1.20 & $512.8 / 135$ & 17 & 85 & 44 \\
\hline & & $512.8 / 213$ & & 85 & 50 \\
\hline \multirow[t]{2}{*}{ RR } & 1.43 & $520.1 / 135$ & 15 & 85 & 44 \\
\hline & & $520.1 / 213$ & & 85 & 50 \\
\hline \multirow[t]{2}{*}{ NOD R } & 2.20 & $825.6 / 135$ & 1 & 140 & 83 \\
\hline & & $825.6 / 70$ & & 90 & 100 \\
\hline \multirow[t]{2}{*}{ YR } & 2.63 & $523.6 / 135$ & 6 & 45 & 20 \\
\hline & & $523.6 / 911$ & & 45 & 20 \\
\hline \multirow[t]{2}{*}{ LR } & 2.78 & $498.6 / 135$ & 17 & 40 & 19 \\
\hline & & $498.6 / 213$ & & 40 & 43 \\
\hline \multirow[t]{2}{*}{ WR } & 3.06 & $535.0 / 135$ & 18 & 40 & 18 \\
\hline & & $535.0 / 213$ & & 40 & 42 \\
\hline \multirow[t]{2}{*}{ LA } & 4.30 & $911.6 / 135$ & 2 & 85 & 90 \\
\hline & & $911.6 / 213$ & & 85 & 65 \\
\hline \multirow[t]{2}{*}{ LY } & 4.40 & $1002.6 / 135$ & 2 & 106 & 96 \\
\hline & & $1002.6 / 213$ & & 106 & 75 \\
\hline \multirow[t]{2}{*}{ LW } & 4.80 & $1025.6 / 135$ & 2 & 111 & 100 \\
\hline & & $1025.6 / 213$ & & 111 & 80 \\
\hline \multirow[t]{2}{*}{ LF } & 4.93 & $986.6 / 135$ & 2.5 & 96 & 95 \\
\hline & & $986.6 / 213$ & & 96 & 73 \\
\hline \multirow[t]{2}{*}{ CYN } & 1.90 (HILIC) & $416.3 / 194$ & 1.5 & 80 & 53 \\
\hline & & $416.3 / 336$ & & 80 & 53 \\
\hline \multirow[t]{2}{*}{ ATX } & 4.10 (HILIC) & $166.1 / 149$ & 1.6 & 60 & 21 \\
\hline & & $166.1 / 131$ & & 60 & 24 \\
\hline
\end{tabular}

a For all compounds the most intense transition is reported in the first line, the less intense in the second line.

b The relative ratios between the intensities of the two MRM transitions are reported in this column.

primer annealing at $53^{\circ} \mathrm{C}$ for $30 \mathrm{~s}$, strand elongation at $72{ }^{\circ} \mathrm{C}$ for $1 \mathrm{~min}$, and a final elongation step at $72{ }^{\circ} \mathrm{C}$ for $5 \mathrm{~min}$. PCR products were checked and separated by $1.5 \%$ agarose gel electrophoresis stained with ethidium bromide. Sizing of DNA fragments were first evaluated with a commercial DNA ladder (GeneRuler Express, Fermentas).

Besides 16S rRNA phylogenetic analyses, taxonomic iden tification of isolates presented in Table 4 was further checked using the rbcLX gene region. rbcLX products ( $878 \mathrm{bp}$ ) were amplified using the primers $\mathrm{CW}$ and $\mathrm{CX}$, following the pro tocols in Rudiet al. (1998), with the exception of the number of cycles in the second cycle step (35 instead of 38 ).

PCR products (16S rRNA and rbcLX genes) were cleaned with Exonuclease plus Shrimp Alcaline Phosphatase (ExoSAP). The same primers as in the PCR (CYA359F and CYA781Ra for $16 \mathrm{~S}$ rRNA) were used with the BigDye Terminator Cycle Sequencing technology (Applied Biosystems), according to the manufacturers' protocols. After purification in automation using the Agencourt CleanSEQ ${ }^{\circledR}$ Kit (Beckman), products were run on an Automated Capillary Electrophoresis Sequencer 3730XL DNA Analyzer (Applied Biosystems). In order to trim the low quality ends, sequences were checked with Chro matogram Explorer 3.3.0 (Heracle Biosoft). Forward and reverse chromatograms were further evaluated and 
Table 4 - (a) Codes of Tychonema bourrellyi strains isolated in Lake Garda (Northern Italy) between February and April 2014, and corresponding ENA accession numbers of $16 S$ rRNA and rbcLX genes. (b) Polymerase chain reaction amplification of ATX and MCs biosynthesis encoding genes ( $\mathrm{anaC}$ and mcyE), and concentrations of anatoxin-a (ATX) and total microcystins (MCs); "+" and " " indicate the presence and absence of expected amplicons using agarose gel electrophoresis. "nd", not detectable.

\begin{tabular}{|c|c|c|c|c|c|c|c|c|}
\hline \multicolumn{5}{|l|}{ (a) } & \multicolumn{4}{|c|}{ (b) } \\
\hline \multirow[t]{2}{*}{ Date } & \multirow[t]{2}{*}{ Isolate number } & \multirow[t]{2}{*}{ Isolate code } & \multicolumn{2}{|c|}{ Accession number } & \multirow[t]{2}{*}{ anac } & \multirow{2}{*}{$\frac{\mathrm{ATX}^{\prime}}{\mu \mathrm{gL}^{1}}$} & \multirow[t]{2}{*}{ mcyE } & \multirow{2}{*}{$\frac{\mathrm{MCs}}{\mu \mathrm{g} \mathrm{L}^{1}}$} \\
\hline & & & $16 \mathrm{~S}$ rRNA & rbclX & & & & \\
\hline \multirow[t]{4}{*}{$11 \mathrm{Feb}$} & 1 & FEM GaT0214 3 & LM997416 & LM997428 & + & 6.44 & & nd \\
\hline & 2 & FEM GaT0214 12 & LM997417 & LM997429 & + & 10.46 & & nd \\
\hline & 3 & FEM GaT0214 16 & LM997418 & LM997430 & + & 11.32 & & nd \\
\hline & 4 & FEM GaT0214 21 & LM997419 & LM997431 & + & 5.76 & & nd \\
\hline \multirow[t]{4}{*}{11 Mar } & 5 & FEM GaT0314 2 & LM997420 & LM997432 & + & 2.92 & & nd \\
\hline & 6 & FEM GaT0314 4 & LM997421 & LM997433 & & nd & & nd \\
\hline & 7 & FEM GaT0314 13 & LM997422 & LM997434 & & nd & & nd \\
\hline & 8 & FEM GaT0314 17 & LM997423 & LM997435 & + & 2.91 & & nd \\
\hline \multirow[t]{4}{*}{$08 \mathrm{Apr}$} & 9 & FEM GaT0414 14 & LM997424 & LM997436 & + & 1.48 & & nd \\
\hline & 10 & FEM GaT0414 16 & LM997425 & LM997437 & + & 2.02 & & nd \\
\hline & 11 & FEM GaT0414 26 & LM997426 & LM997438 & + & 1.55 & & nd \\
\hline & 12 & FEM GaT0414 27 & LM997427 & LM997439 & + & 0.48 & & nd \\
\hline
\end{tabular}

assembled using the BioEdit 7.2.5 sequence alignment editor (Hall, 1999). Sequences were deposited to the European Nucleotide Archive (ENA) and analysed with Megablast (NCBI) against 16S rRNA and rbcLX gene sequences.

In addition to the toxins analyses (Section 2.4), the isolated strains were analysed for the presence of MCs and ATX encoding genes. The presence of $m c y E$ genes was evaluated according to the PCR protocols of Rantala et al. (2006) using general primers (mcyE F2/R4) and Anabaena 90 as a positive control (Ana 90; UHCC). The presence of anatoxin a synthe tase gene (anaC) was determined using the primer pairs anaC osc, Osc 193 (UHCC) as positive control, and the methods described in Rantala Ylinen et al. (2011b).

\subsection{Comparison with Norwegian Tychonema strains}

Eight Tychonema bometii and Tychonema bourrellyi strains iso lated in Norway between 1976 and 1982 from phytoplankton samples collected in the River Glåma and Lake Mjøsa were included in the study. The eight Norwegian Tychonema strains are cultivated in the culture collection of algae of the
Norwegian Institute for Water Research (NIVA cca). DNA extraction was conducted according to Ballot et al. (2014), PCR and sequencing of the $16 \mathrm{~S}$ rRNA gene was conducted using the methods described in Ballot et al. (2008). The Norwegian Tychonema sp. strains were investigated for the production of MC and ATX using the Abraxis Microcystins/Nodularins (ADDA), ELISA Kit and the Abraxis Anatoxin a Receptor Binding Assay (Biosense, Bergen, Norway) respectively. The same strains were tested for the anaF encoding gene using the primers atxoaf and atxoar and the protocol according to Ballot et al. $(2010,2014)$. The presence of $m c y E$ genes was evaluated according to the PCR protocols of Rantala et al. (2006) using general primers (mcyE F2/R4). Sequences were submitted to ENA.

\subsection{Phylogenetic analysis}

The $16 \mathrm{~S}$ rRNA genes of the 20 Tychonema strains listed in Tables 4 and 5 were analysed using molecular sequence as sembly software Seqassem version 04/2008 (Sequentix Digital DNA processing, Klein Raden, Germany). The Align

Table 5 - (a) Codes of Tychonema bourrellyi strains isolated in Lake Mjøsa and River Glåma (Norway), and corresponding ENA accession numbers of $16 S$ rRNA genes. (b) Polymerase chain reaction amplification of anaF and mcyE genes, and positive or negative detection of anatoxin-a (ATX-a) and total microcystins (MCs) measured using ELISA Kit and Anatoxin-a Receptor-Binding Assay. "+" and " " indicate the presence and absence of expected amplicons using agarose gel electrophoresis (anaF and mcyE), and the presence and absence of corresponding toxins (ATX, MCs), respectively.

\begin{tabular}{|c|c|c|c|c|c|c|c|c|}
\hline \multicolumn{5}{|l|}{ (a) } & \multicolumn{4}{|c|}{ (b) } \\
\hline Code & Year of isolation & Species & Origin & Accession number $16 \mathrm{~S}$ rRNA & anaF & ATX & mcyE & MCs \\
\hline NIVA CYA $33 / 1$ & 1976 & T. bourrellyi & Lake Mjøsa & LM651410 & & & & \\
\hline NIVA CYA $33 / 3$ & 1976 & T. bourrellyi & Lake Mjøsa & LM651411 & & & & \\
\hline NIVA CYA $33 / 4$ & 1976 & T. bourrellyi & Lake Mjøsa & LM651412 & & & & \\
\hline NIVA CYA $33 / 5$ & 1976 & T. bourrellyi & Lake Mjøsa & LM651413 & & & & \\
\hline NIVA CYA 60 & 1978 & T. bornetii & Lake Mjøsa & LM651414 & + & & & \\
\hline NIVA CYA 95 & 1982 & T. bornetii & River Glåma & LM651415 & & & & \\
\hline NIVA CYA $96 / 1$ & 1982 & T. bourrellyi & Lake Mjøsa & LM651416 & & & & \\
\hline NIVA CYA $96 / 3$ & 1982 & T. bourrellyi & Lake Mjøsa & LM651417 & + & + & & \\
\hline
\end{tabular}


(version 03/2007) MS Windows based manual sequence alignment editor (SequentiX - Digital DNA processing, Klein Raden, Germany) was used to obtain DNA sequence align ments, which were then corrected manually. Segments with highly variable and ambiguous regions and gaps making proper alignment impossible were excluded from the ana lyses. A 16S rRNA gene set containing 405 bp was used. Gloeobacter violaceus (AF132790) was employed as outgroup in the 16S rRNA tree. Thirty three additional Oscillatoriales from GenBank were included in the 16S rRNA gene sequence analysis.

A phylogenetic tree for 16S rRNA gene sequences was constructed using the maximum likelihood (ML) algorithm with 1000 bootstrap replicates. In the ML analysis, evolu tionary substitution model was evaluated in MEGA version 6 (Tamura et al., 2013) and K2 + G + I was found to be the best fitting evolutionary model for the 16S rRNA gene.

\section{Results}

\subsection{Environmental samples}

In the first $20 \mathrm{~m}$, water temperatures in the three sampling dates ranged between 9.1 and $12.4{ }^{\circ} \mathrm{C}$ (Table 2). An incipient stratification was apparent beginning in April. DIN and TP concentrations were in the range 232-342 $\mu \mathrm{g} \mathrm{N} \mathrm{L}{ }^{1}$ and 10-16 $\mu$ g P L ${ }^{1}$. The euphotic depth was between 22 and $27 \mathrm{~m}$.

\subsection{Microscopic examinations}

Over 65 cultures were obtained from the isolation of single filaments collected in February, March and April. In the orig inal samples, the filaments were solitary and free floating, pale red, sometimes longer than $2 \mathrm{~mm}$. All the specimens looked quite different from the filaments of Planktothrix rubescens, the predominant cyanobacterium in Lake Garda, and more similar to other Phormidioideae, namely Tychonema spp. (Komárek and Albertano, 1994; Komárek and Anagnostidis, 2007). A first preliminary round of PCR and sequencing with the reverse primer CYA781Ra on 24 cultures matched well to various Tychonema species (similarity be tween $99 \%$ and $100 \%$ ), as well as to sheathed Oscillatoriales (Phormidium, Microcoleus) (see Section 3.3).

In the algal cultures, filaments were colourless or pale purplish/brown, rarely green, unbranched and without apparent firm sheaths. Cells usually were more or less isodi ametric, with widths between 4.5 and $7 \mu \mathrm{m}$ (Fig. 1). In some cultures, cells looked shorter $(<5 \mu \mathrm{m})$ than wide (e.g. Fig. $1 \mathrm{~d}$, e). Filaments looked immotile or slightly trembling, with rounded apical cells, without calyptra and with no or very slight attenuation at the ends. In some specimens, the width changed slightly along the filaments (e.g., Fig. 1a, c, d). Sometimes, the cells had clearly visible large holes, similar to "vacuoles" (quite apparent in Fig. 1a, c), which, actually, are widened thylakoids (Komárek and Albertano, 1994). The cen tripetal formation of the cross walls was often easily detect able (e.g., arrows in Fig. 1b). These characteristics were consistent with the diacritical features described for $\mathrm{T}$. bour rellyi. However, taking into account that planktonic

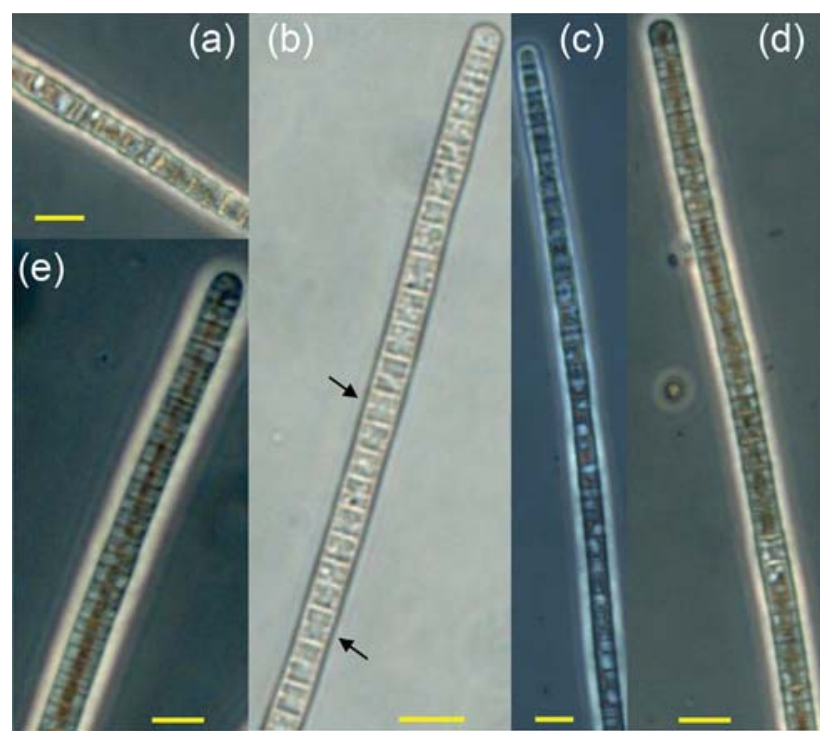

Fig. 1 - Micrographs of Tychonema isolated from samples collected in Lake Garda in (a) February, (b, c) March and (d, e) April. Scale bars $10 \mu \mathrm{m}$. From (a) to (e), filaments are 5.7, 5.8, 5.2, 5.3 and $6.8 \mu \mathrm{m}$ wide, respectively. The arrows in (b) indicate the centripetal formation of the cross wall. Observations made at $400 \times$ and phase contrast.

populations of Tychonema tenue could possibly be identical to T. bourrellyi (Komárek and Anagnostidis, 2007), the micro scopic discrimination of these two species in pelagic envi ronments is not straightforward.

\subsection{Sequences and phylogenetic analyses}

The morphological determination of the isolated strains was supported by phylogenetic analyses based on 16S rRNA per formed on the 12 selected strains in Table 4. Phylogenetic re lationships of the investigated strains are presented in the ML tree of the 16S rRNA region of Oscillatoriales strains (Fig. 2). All 16S rRNA sequences from the Italian and Norwegian Tycho nema strains (Tables 4 and 5) were grouped in a distinct cluster together with Tychonema sequences derived from GenBank. The Tychonema cluster was very closely related to a Phormidium autumnale and a Microcoleus antarcticus strain (Fig. 2). The whole cluster was supported by a bootstrap value of $96 \%$.

These findings were further confirmed by a BLAST (NCBI) homology search. Results showed that the rbcLX gene regions sequenced in the 12 selected strains (Table 4) were $>99 \%$ similar to T. bourrellyi (7 strains) and T. bornetii (1 strain).

\subsection{Toxicity of the single strains}

Of the 24 strains of Tychonema isolated from Lake Garda and submitted to LC-MS analyses, 14 produced ATX, although in some cases, at very low concentrations (3 isolates with ATX $<0.1 \mu \mathrm{g} \mathrm{L}^{1}$ ). A typical LC-MS chromatogram, showing the analyses of standards (ATX and CYN) and of a represen tative sample is reported in Fig. 3. The molecular analyses 


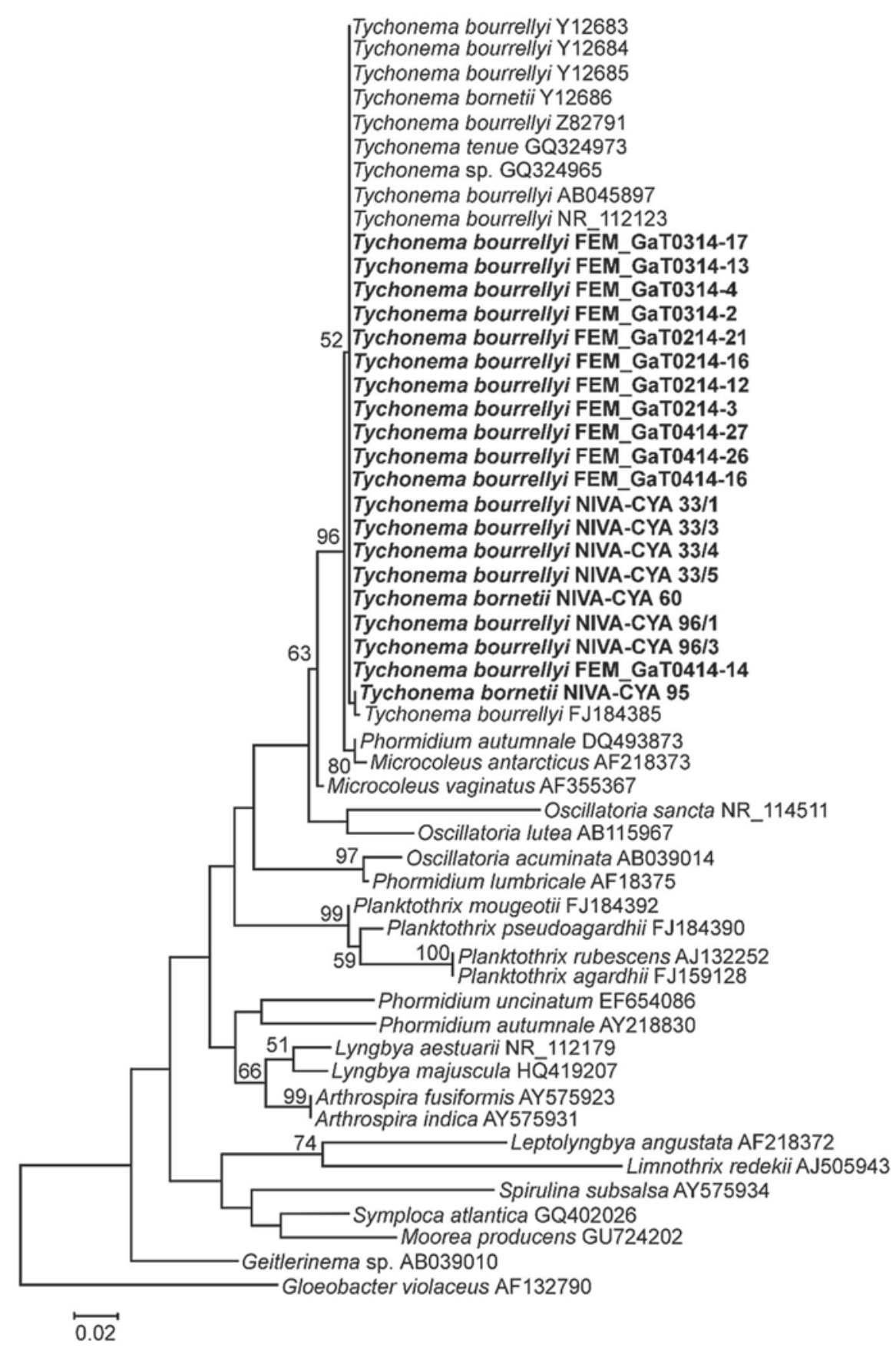

Fig. 2 - Maximum likelihood tree determined on the basis of partial 16S rRNA gene sequences of 53 Oscillatoriales strains. Outgroup Gloeobacter violaceus (AF132790). Strains from this study are marked in bold. Bootstrap values above 50 are included. The scale bar indicates $2 \%$ sequence divergence.

allowed amplifying the anaC encoding gene fragment of the anatoxin a synthetase (ana) gene cluster. In the same group of 24 isolates, PCR products were identified in 11 strains. No anaC PCR products were identified in all the non ATX producing strains, and in the 3 culture samples with very low concen trations of $\operatorname{ATX}\left(<0.1 \mu \mathrm{g} \mathrm{L}{ }^{1}\right)$.

A representative picture of the anaC products amplified with anaC osc primers in the 12 selected strains subjected to phylogenetic analysis and included in Table 4 is reported in Fig. 4. In these 12 selected strains, the cell quota of ATX on a biovolume basis were between 1.3 and $2.6 \mu \mathrm{g} \mathrm{mm}{ }^{3}$ in February, 0.1 and $0.3 \mu \mathrm{g} \mathrm{mm}{ }^{3}$ in March, and 0.2 and $1.8 \mu \mathrm{g} \mathrm{mm}{ }^{3}$ April. On a cell basis, corresponding values were in the range $0.18-0.35 \mathrm{pg}$ cell ${ }^{1}$ (February), $0.01-0.04 \mathrm{pg}^{1}$ cell ${ }^{1}$ (March) and 0.02-0.20 pg cell ${ }^{1}$ (April).

As for the strains isolated in the Norwegian freshwaters (Table 5), T. bourrellyi strain NIVA CYA 96/3 was confirmed as ATX producer using the Abraxis Anatoxin a Receptor Binding Assay, while the other seven strains from NIVAcca tested negative for ATX. T. bourrellyi strain NIVA CYA 96/3 and T. 


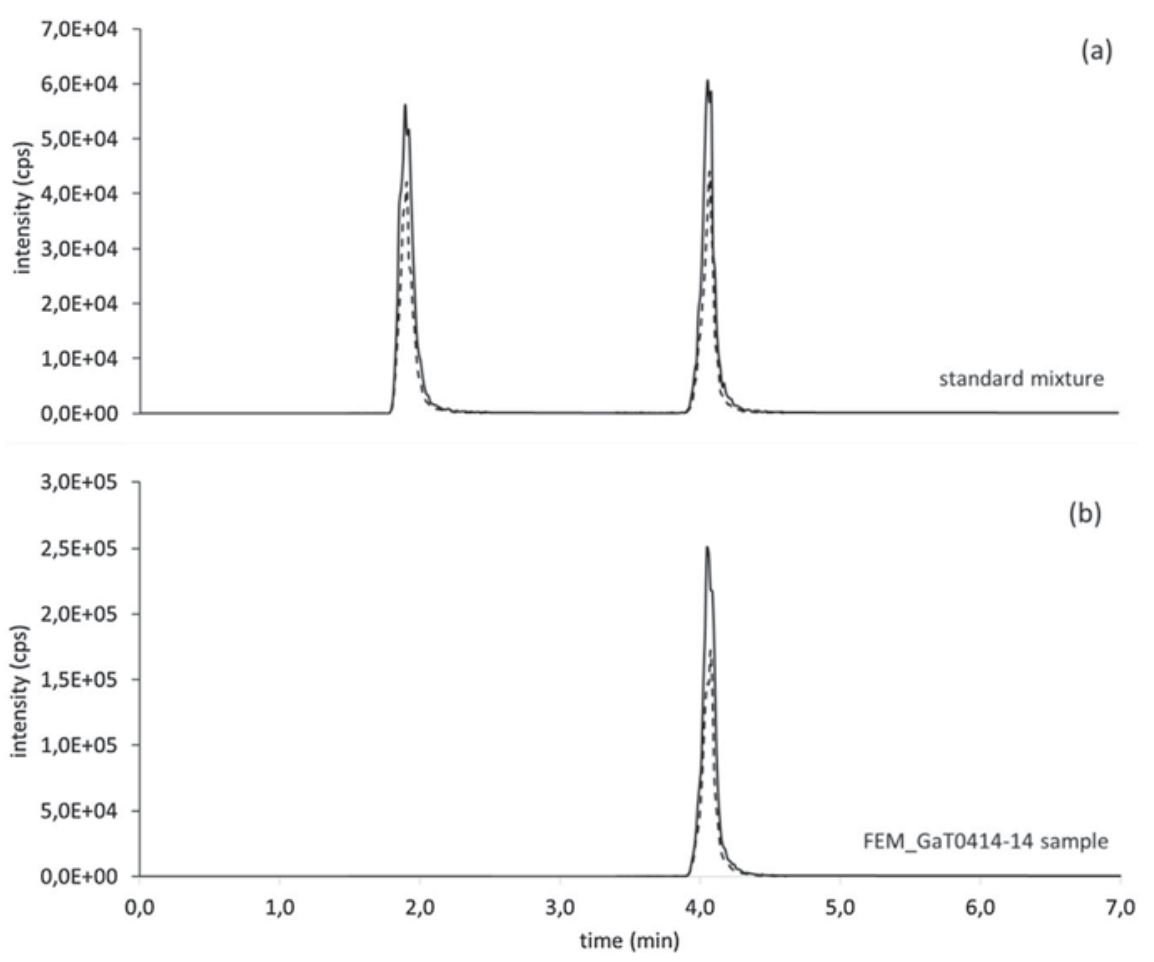

Fig. 3 - Liquid chromatography-mass spectrometry chromatograms resulting from the injections of a mixture of pure standards of cylindrospermopsin $(50 \mathrm{ng} / \mathrm{mL})$ and anatoxin-a $\left(165 \mathrm{ng} \mathrm{mL}{ }^{1}\right)$ (panel a) and of an extract of a Tychonema culture (panel b). For each toxin, the traces of the two monitored MRM transitions are shown (solid and dashed lines).

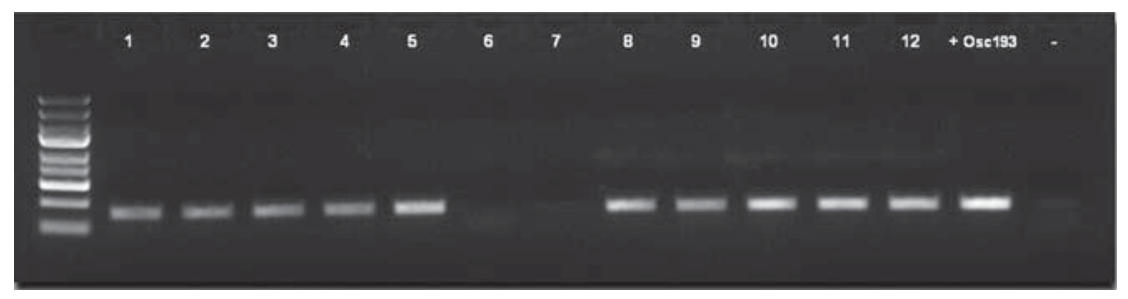

Fig. 4 - PCR products amplified with anac-osc primers (Rantala-Ylinen et al., 2011b). Samples from 1 to 12 are coded as in Table 4. "+" positive (Osc-193 UHCC strain) and “ " negative controls. Size of the ladder (in base pairs): 100, 300, 500, 750, $1000,1500,2000,3000,5000$. The amplicon products are located between the bands $100-300 \mathrm{bp}$.

bornetii strain NIVA CYA 60 tested positive for anaF of the ATX synthetase (ana) gene cluster (accession numbers LM651418 and LN555581, respectively).

None of the Italian and Norwegian Tychonema strains were positive for $\mathrm{MC}$, which was also confirmed by the absence of mcyE PCR products in all the samples analysed (Tables 4 and 5).

\section{Discussion}

After establishing several cultures of potentially toxic fila mentous Cyanobacteria collected in Lake Garda, we discov ered that Tychonema is able to produce ATX. This is the first discovery of a planktonic genus belonging to the Oscillator iales able to produce ATX. These findings were confirmed with the discovery of ATX producing Tychonema strains isolated in Norway.

The discovery of Tychonema in Lake Garda was quite un expected. The predominant Oscillatoriales in this lake and in the other large lakes south of the Alps (Iseo, Como, Lugano and Maggiore) is P. rubescens (Salmaso et al., 2012). Neverthe less, the high number of isolates of $P$. rubescens analysed so far by molecular methods (16S rRNA, rpoC1, rbcLX genes) in these lakes referred to samples mostly collected during the late spring and summer months, i.e. when the biomass develop ment of this species was at its seasonal maximum (P. rubescens accession numbers are reported in D'Alelio et al., 2012, 2013). During winter, the abundances of $P$. rubescens and of the other Oscillatoriales (Limnothrix sp., Planktolyngbya limnetica) in Lake Garda are very low (Salmaso, 2011). In the work presented here, the isolation of filaments of Tychonema was possible on 
samples collected by means of plankton nets, and filtering $0.5-1 \mathrm{~m}^{3}$ of lake water. Filaments in the samples collected with the Niskin bottles were rare and difficult to isolate. The presence of Tychonema appeared almost exclusive, because only a few filaments of $P$. rubescens were isolated from the net samples. On the other hand, the concurrent presence of $P$. rubescens was confirmed by molecular analysis carried out by checking the presence of rbcLX PCR products (see D'Alelio et al., 2013) on the environmental samples collected from February and April between the surface and $60 \mathrm{~m}$ (data not shown).

Tychonema is considered a cold stenotherm genus of northern temperate regions (Komárek et al., 2003). Abundant populations of $\mathrm{T}$. bourrellyi were documented particularly in northern Europe and Canada (Lund, 1955; Skulberg and Skulberg, 1985; Rudi et al., 1998; Komárek et al., 2003). In Lake Garda, the presence of this species in the colder months is consistent with these features. On the other side, the absence of gas vesicles, and therefore the inability to control buoyancy and vertical position, can represent a negative se lective characteristic in deep and large lakes during the stratification months. The ecological role of the large "vacu oles", which are particularly apparent in the older cells, is still unclear. The large intracellular "holes" are due to the widened thylacoid membranes enveloping the enlarged intra thylacoidal spaces. Electron microscopy showed that these spaces were filled with electron dense fibrillar structures or globules similar to polyphosphate bodies (Komárek and Albertano, 1994). It is interesting to observe that another species - Tychonema sequanum - was identified by microscopic methods in Lake Maggiore (Kamenir and Morabito, 2009). This taxon, however, has smaller dimensions (2.5-5 $\mu \mathrm{m}$ width) compared to T. bourrellyi. Recently, T. bourrellyi was recorded also in Lake Erhai, in China. Comparative analyses of the $16 \mathrm{~S}$ rDNA gene sequences determined from filaments isolated in this lake confirmed that the Chinese strains were grouped with T. bourrellyi/T. tenue (Wei et al., 2012).

The number of genera known to produce ATX is quite limited, especially when the list of producers is restricted to the only cases determined on species isolated and analysed in culture (Table 1). In Italy, reports of ATX are quite rare, refer ring exclusively to environmental samples (e.g., Cerasino and Salmaso, 2012). The production of ATX was associated with blooms or higher development of Anabaena planctonica (Doli chospermum planctonicum) (Bruno et al., 1994), Anabaena crassa (D. crassum) (Messineo et al., 2009) and "a peculiar P. rubescens population" (Viaggiu et al., 2004; Messineo et al., 2009). How ever, the ability of isolated populations of these species to produce ATX in culture conditions was not confirmed.

So far, the only Oscillatoriales proven to produce ATX in isolated populations belonged to the genera Oscillatoria and Phormidium (Table 1). These taxa are mostly detected in benthic or periphytic substrates. In contrast, T. bourrellyi is known to develop pelagic populations (as in our study), opening new perspectives about the ability of pelagic Oscil latoriales to produce ATX. Taking into consideration the positive amplification of anaF genes in the strains of $\mathrm{T}$. bour rellyi and $\mathrm{T}$. bornetii isolated in Norway, the ability to produce ATX does not seem to be restricted to specific climatic regions or isolated populations. On the other hand, the high variability of the ATX quota in the isolates of T. bourrellyi grown under standard conditions suggests the existence of differences in the ability to produce ATX in strains isolated in different months. Overall, differences in the cell quota in the isolates of Lake Garda were between 0.01 and 0.35 pg cell ${ }^{1}$, i.e. within more than 1 order of magnitude, but well within the range estimated in cultures of $P$. autumnale grown under different iron and copper stress conditions (between ca. 0 and 1.2 pg cell ${ }^{1}$; Harland et al., 2013), and within the variations observed in natural benthic Phormidium mats (100 fold differ ences in ATX quota; Wood et al., 2012).

The primers anaC osc were specifically designed to amplify the anaC gene in the Oscillatoria genus (Rantala Ylinen et al., 2011b). These primers proved to be useful also in the amplification of the anaC genes in Tychonema, suggesting the potential for a wider application of these specific protocols also to other Oscillatoriales. Similar considerations apply to the atxoaf $\mathrm{r}$ primers, which were originally designed to detect Aphanizomenon species and other cyanobacteria (Ballot et al., 2010, 2014). In perspective, the comparison of the ana gene cluster encoding ATX in Tychonema and in the other cyano bacteria will provide further insight for the design of protocols tailored for the detection of pelagic ATX producers (cf. Méjean et al., 2014).

Overall, our findings open new perspectives in the study of the ecology of phytoplankton and cyanotoxins producers in Lake Garda and in the deep alpine and subalpine lakes. The new discovery of Tychonema in Lake Garda will require to be studied in detail by evaluating the seasonal and spatial dy namics, distribution and diversity, as well as toxic potential assessed both in environmental and isolated strains. An open question that needs to be dealt with is the significance of this appearance and its potential evolution particularly in relation with the very recent oligotrophication of the lake and the decrease of P. rubescens populations (Salmaso and Cerasino, 2012).

\section{Conclusions}

In the work presented here, we identified a new pelagic cyanobacterium belonging to the Oscillatoriales able to syn thesize ATX. This species - T. bourrellyi - was isolated for the first time in the largest Italian lake (Lake Garda) during the winter and spring months.

- The identification of the species was carried out using a polyphasic approach, based on the microscopic identifi cation of diacritical characters, molecular methods (16S rRNA and rbcLX genes) and phylogenetic analyses.

- Isolates of Tychonema were able to produce consistent amounts of ATX. The identification of this new ATX pro ducer was also verified by the amplification of the anaC genes involved in the biosynthesis of ATX. These new findings were confirmed by the concurrent analyses of Tychonema strains isolated in Norway.

- The significance and impact of Tychonema producing ATX will require additional evaluation by studying the seasonal dynamics and toxic potential of populations in relation to 
the development of other toxic cyanobacteria as well as in a wider geographical context.

- This study further highlights how the number of cyano toxins producers in the freshwater environments is possibly still underestimated. On the other hand, the way in which these results originated, suggests that the only reliable strategy to identify cyanotoxins producers should be based on the isolation of strains and their identification with a polyphasic approach associated to a concurrent metabolomic profiling performed with advanced analytical techniques.

\section{Acknowledgements}

Investigations in Lake Garda were made in the framework of the LTER (Long Term Ecological Research) Italian network, site "Southern Alpine lakes", IT08 000 A (http://www.lteritalia.it/). The activity was supported by $\mathrm{PhD}$ fellowships to S.S. and C.C. from the E. Mach Foundation - Istituto Agrario di S. Michele all'Adige (FIRST FEM International Research School). We thank the European Cooperation in Science and Technology COST Action ES1105 CYANOCOST for networking and knowledge transfer support as well as the Marie Curie International Research Staff Exchange Fellowship within the 7th European Community Framework Program (PIRSES GA 2011 295223) for supporting researcher exchanges.

\section{R E F E R E N C E S}

APHA, AWWA, WEF, 2000. Standard Methods for the Examination of Water and Wastewater, 19th ed. American Public Health Association, Washington.

Aráoz, R., Nghiêm, H.O., Rippka, R., Palibroda, N., Tandeau de Marsac, N., Herdman, M., 2005. Neurotoxins in axenic oscillatorian cyanobacteria: coexistence of anatoxin a and homoanatoxin a determined by ligand binding assay and GC/ MS. Microbiology 151, 12631273.

Aráoz, R., Molgó, J., Tandeau de Marsac, N., 2010. Neurotoxic cyanobacterial toxins. Toxicon 56 (5), 813828.

Ballot, A., Dadheech, P.K., Haande, S., Krienitz, L., 2008. Morphological and phylogenetic analysis of Anabaenopsis abijatae and Anabaenopsis elenkinii (Nostocales, Cyanobacteria) from tropical inland water bodies. Microb. Ecol. 55, 608618.

Ballot, A., Fastner, J., Lentz, M., Wiedner, C., 2010. First report of anatoxin a producing cyanobacterium Aphanizomenon issatschenkoi in northeastern Germany. Toxicon 56, 964971.

Ballot, A., Sandvik, M., Rundberget, T., Botha, C.J., Miles, C.O., 2014. Diversity of cyanobacteria and cyanotoxins in Hartbeespoort Dam, South Africa. Mar. Freshw. Res. 65, 175189.

Boyer, G.L., Zimba, R.V., 2007. Production of the cyanobacterial toxin microcystin in black band disease of corals. FEMS Microbiol. Lett. 272, 182187.
Bruno, M., Barbini, D.A., Pierdominici, E., Serse, A.P., Ioppolo, A., 1994. Anatoxin a and a previously unknown toxin in Anabaena planctonica from blooms found in Lake Mulargia (Italy). Toxicon 32 (3), 369373.

Cadel Six, S., Iteman, I., Peyraud Thomas, C., Mann, S. Ploux, O., Méjean, A., 2009. Identification of a polyketide synthase coding sequence specific for anatoxin a producing Oscillatoria cyanobacteria. Appl. Environ. Microbiol. 75 (14), 49094912.

Carrasco, D., Moreno, E., Paniagua, T., Hoyos, C.D., Wormer, L., Sanchis, D., Cirés, S., Martín Del Pozo, D., Codd, G.A., Quesada, A., 2007. Anatoxin a occurrence and potential cyanobacterial anatoxin a producers in Spanish reservoirs. J. Phycol. 43 (6), 11201125.

Cerasino, L., Salmaso, N., 2012. Diversity and distribution of cyanobacterial toxins in the Italian subalpine lacustrine district. Oceanol. Hydrobiol. Stud. 41 (3), 5463.

D'Alelio, D., Gandolfi, A., 2012. Recombination signals in the rpoC1 gene indicate gene flow between Planktothrix (Cyanoprokaryota) species. J. Phycol. 48 (6), 14241432.

D'Alelio, D., Salmaso, N., Gandolfi, A., 2013. Frequent recombination shapes the epidemic population structure of Planktothrix (cyanoprokaryota) in Italian sub alpine lakes. J. Phycol. 49, 11071117.

Edwards, C., Beattie, K.A., Scrimgeour, C.M., Codd, G.A., 1992. Identification of Anatoxin a in benthic cyanobacteria (blue green algae) and in associated dog poisonings at Loch Insh, Scotland. Toxicon 30 (10), 11651175.

Hall, T.A., 1999. BioEdit: a user friendly biological sequence alignment editor and analysis program for Windows 95/98/NT Nucleic Acids Symp. Ser. 41, 9598.

Harland, F.M.J., Wood, S.A., Moltchanova, E., Williamson, W.M., Gaw, S., 2013. Phormidium autumnale growth and anatoxin a production under iron and copper stress. Toxins 5 (12), 25042521.

Harland, F., Wood, S., Broady, P., Gaw, S., Williamson, W., 2014. Polyphasic studies of cyanobacterial strains isolated from benthic freshwater mats in Canterbury, New Zealand. N. Z. J. Bot. 52, 116135.

Hodoki, Y., Ohbayashi, K., Kobayashi, Y., Takasu, H., Okuda, N., Nakano, S.I., 2013. Anatoxin a producing Raphidiopsis mediterranea Skuja var. grandis Hill is one ecotype of non heterocytous Cuspidothrix issatschenkoi (Usačev) Rajaniemi et al. in Japanese lakes. Harmful Algae 21 22, 4453.

Humpage, A.R., Froscio, S.M., Lau, H.M., Murphy, D., Blackbeard, J., 2012. Evaluation of the Abraxis Strip Test for Microcystins ${ }^{\mathrm{TM}}$ for use with wastewater effluent and reservoir water. Water Res. 46, 15561565.

Kamenir, Y., Morabito, G., 2009. Lago Maggiore oligotrophication as seen from the long term evolution of its phytoplankton taxonomic size structure. J. Limnol. 68, 146161.

Kirk, J.T.O., 1994. Light and Photosynthesis in Aquatic Ecosystems, second ed. Cambridge University Press, Cambridge. 509 pp.

Kleinteich, J., Wood, S.A., Küpper, F.C., Camacho, A., Quesada, A., Frickey, T., Dietrich, D.R., 2012. Temperature related changes in polar cyanobacterial mat diversity and toxin production. Nat. Clim. Change 2, 356360.

Komárek, J., Albertano, P., 1994. Cell structure of a planktic cyanoprokaryote, Tychonema bourrellyi. Algol. Stud. Arch. Hydrobiol (Suppl. 75), 157166.

Komárek, J., Komárková, J., Kling, H., 2003. Filamentous cyanobacteria. In: Wehr, J.D., Sheath, R.G. (Eds.), Freshwater Algae of North America. Academic Press, Elsevier Science, San Diego, pp. 117196.

Komárek, J., Anagnostidis, K., 2007. Cyanoprokariota. Part 2: Oscillatoriales. Süßwasserflora von Mitteleuropa, Band 19/2. Springer, Spektrum, 759 pp. 
Kotai, J., 1972. Instructions for Preparation of Modified Nutrient Solution Z8 for Algae. Publication B 11/69. Norwegian Institute for Water Research, Oslo, Norway.

Lakshmana Rao, P., Bhattacharya, R., Gupta, N., Parida, M., Bhaskar, A., Dubey, R., 2002. Involvement of caspase and reactive oxygen species in cyanobacterial toxin anatoxin a induced cytotoxicity and apoptosis in rat thymocytes and Vero cells. Arch. Toxicol. 76 (4), 227235.

Lee, E., Ryan, U.M., Monis, P., McGregor, G.B., Bath, A., Gordon, C., Paparini, A., 2014. Polyphasic identification of cyanobacterial isolates from Australia. Water Res. 59, 248261.

Lund, J.W.G., 1955. Contributions to our knowledge of British algae. XIV. Three new species from the English Lake District. Hydrobiologia 7, 219228.

Mankiewicz Boczek, J., Gągała, I., Kokociński, M., Jurczak, T., Stefaniak, K., 2011. Perennial toxigenic Planktothrix agardhii bloom in selected lakes of Western Poland. Environ. Toxicol. 26, 1020.

Méjean, A., Mann, S., Maldiney, T., Vassiliadis, G., Lequin, O., Ploux, O., 2009. Evidence that biosynthesis of the neurotoxic alkaloids anatoxin a and homoanatoxin a in the cyanobacterium Oscillatoria PCC 6506 occurs on a modular polyketide synthase initiated by L proline. J. Am. Chem. Soc. 131 (22), 75127513.

Méjean, A., Mann, S., Vassiliadis, G., Lombard, B., Loew, D., Ploux, O., 2010. In vitro reconstitution of the first steps of anatoxin a biosynthesis in Oscillatoria PCC 6506: from free L proline to acyl carrier protein bound dehydroproline. Biochemistry 49 (1), 103113.

Méjean, A., Paci, G., Gautier, V., Ploux, O., 2014. Biosynthesis of anatoxin a and analogues (anatoxins) in cyanobacteria. Toxicon 91, 1522.

Meriluoto, J., Codd, G.A. (Eds.), 2005. TOXIC: Cyanobacterial Monitoring and Cyanotoxin Analysis. Åbo Akademi University Press, Turku, p. 149.

Messineo, V., Bogialli, S., Melchiorre, S., Sechi, N., Lugliè, A., Casiddu, P., Mariani, M.A., Padedda, B.M., Corcia, A.D., Mazza, R., Carloni, E., Bruno, M., 2009. Cyanobacterial toxins in Italian freshwaters. Limnologica 39 (2), 95106.

Metcalf, J.S., Codd, G.A., 2012. Cyanotoxins. In: Whitton, B.A. (Ed.), Ecology of Cyanobacteria II: Their Diversity in Space and Time. Springer, Dordrecht, pp. 651675.

Metcalf, J.S., Richer, R., Cox, P.A., Codd, G.A., 2012. Cyanotoxins in desert environments may present a risk to human health. Sci. Total Environ. 421 422, 118123.

Nübel, U., Garcia Pichel, F., Muyzer, G., 1997. PCR primers to amplify 16S rRNA genes from cyanobacteria. Appl. Environ. Microbiol. 63 (8), 33273332.

Osswald, J., Rellán, S., Gago Martinez, A., Vasconcelos, V., 2009. Production of anatoxin a by cyanobacterial strains isolated from Portuguese fresh water systems. Ecotoxicology 18 (8), 11101115.

Paerl, H.W., Steppe, T.F., Buchan, K.C., Potts, M., 2003. Hypersaline cyanobacterial mats as indicators of elevated tropical hurricane activity and associated climate change. AMBIO 32, 8790.

Paerl, H.W., Paul, V.J., 2012. Climate change: links to global expansion of harmful cyanobacteria. Water Res. 46, 13491363.

Pearson, L.A., Neilan, B.A., 2008. The molecular genetics of cyanobacterial toxicity as a basis for monitoring water quality and public health risk. Curr. Opin. Biotechnol. 19 (3), 281288

Quiblier, C., Wood, S., Echenique Subiabre, I., Heath, M., Villeneuve, A., Humbert, J.F., 2013. A review of current knowledge on toxic benthic freshwater cyanobacteria ecology, toxin production and risk management. Water Res. 47 (15), 54645479.
Rantala, A., Rajaniemi Wacklin, P., Lyra, C., Lepistö, L., Rintala, J., Mankiewicz Boczek, J., Sivonen, K., 2006. Detection of microcystin producing cyanobacteria in Finnish lakes with genus specific microcystin synthetase gene E (mcyE) PCR and associations with environmental factors. Appl. Environ. Microbiol. 72 (9), 61016110.

Rantala Ylinen, A., Sipari, H., Sivonen, K., 2011a. Molecular methods: chip assay and quantitative real time PCR: in detecting hepatotoxic cyanobacteria. Methods Mol. Biol. 739, 7386.

Rantala Ylinen, A., Känä, S., Wang, H., Rouhiainen, L., Wahlsten, M., Rizzi, E., Berg, K., Gugger, M., Sivonen, K., 2011b. Anatoxin a synthetase gene cluster of the cyanobacterium Anabaena sp. strain 37 and molecular methods to detect potential producers. Appl. Environ. Microbiol. 77, 72717278.

Rudi, K., Skulberg, O.M., Jakobsen, K.S., 1998. Evolution of cyanobacteria by exchange of genetic material among phyletically related strains. J. Bacteriol. 180, 34533461.

Salmaso, N., 2011. Interactions between nutrient availability and climatic fluctuations as determinants of the long term phytoplankton community changes in Lake Garda, Northern Italy. Hydrobiologia 660, 5968.

Salmaso, N., Cerasino, L., 2012. Long term trends and fine year to year tuning of phytoplankton in large lakes are ruled by eutrophication and atmospheric modes of variability. Hydrobiologia 698, 1728.

Salmaso, N., Mosello, R., 2010. Limnological research in the deep southern subalpine lakes: synthesis, directions and perspectives. Adv. Oceanogr. Limnol. 1, 2966.

Salmaso, N., Buzzi, F., Garibaldi, L., Morabito, G., Simona, M., 2012. Effects of nutrient availability and temperature on phytoplankton development: a case study from large lakes south of the Alps. Aquat. Sci. 74, 555570.

Sivonen, K., 2008. Emerging high throughput analyses of cyanobacterial toxins and toxic cyanobacteria. Adv. Exp. Med. Biol. 619, 539557.

Sivonen, K., Himberg, K., Luukkainen, R., Niemelä, S.I., Poon, G.K., Codd, G.A., 1989. Preliminary characterization of neurotoxic cyanobacteria blooms and strains from Finland. Environ. Toxicol. 4, 339352.

Skulberg, O.M., Skulberg, R., 1985. Planktonic species of Oscillatoria (Cyanophyceae) from Norway characterization and classification. Algol. Stud. Arch. Hydrobiol. 38 39, 157174.

Tamura, K., Stecher, G., Peterson, D., Filipski, A., Kumar, S., 2013. MEGA6: molecular evolutionary genetics analysis version 6.0. Mol. Biol. Evol. 30, 27252729.

Van Apeldoorn, M.E., Van Egmond, H.P., Speijers, G.J.A., Bakker, G.J.I., 2007. Toxins of cyanobacteria. Mol. Nutr. Food Res. 51 (1), 760.

Vandamme, P., Pot, B., Gillis, M., De Vos, P., Kersters, K., Swings, J., 1996. Polyphasic taxonomy, a consensus approach to bacterial systematics. Microbiol. Mol. Biol. Rev. 60, 407438.

Viaggiu, E., Melchiorre, S., Volpi, F., Di Corcia, A., Mancini, R., Garibaldi, L., Crichigno, G., Bruno, M., 2004. Anatoxin a toxin in the cyanobacterium Planktothrix rubescens from a fishing pond in northern Italy. Environ. Toxicol. 19, 191197.

Wei, Z.H., Zhu, M.L., Yu, G.L., Li, R.H., 2012. Occurrence of planktonic cyanobacterium Tychonema bouurrellyi in Erhai lake and its taxonomic studies. Acta Hydrobiol. Sin. 36, 11711175.

Wood, S.A., Rasmussen, J.P., Holland, P.T., Campbell, R., Crowe, A.L.M., 2007a. First report of the cyanotoxin anatoxin a from Aphanizomenon issatschenkoi (Cyanobacteria). J. Phycol. 43, 356365.

Wood, S.A., Selwood, A.I., Rueckert, A., Holland, P.T., Milne, J.R., Smith, K.F., Smits, B., Watts, L.F., Cary, C.S., 2007b. First report of homoanatoxin a and associated dog neurotoxicosis in New Zealand. Toxicon 50, 292301. 
Wood, S.A., Heath, M.W., Kuhajek, J., Ryan, K.G., 2010. Fine scale spatial variability in anatoxin a and homoanatoxin a concentrations in benthic cyanobacterial mats: implication for monitoring and management. J. Appl. Microbiol. 109, 20112018.

Wood, S.A., Smith, F.M., Heath, M.W., Palfroy, T., Gaw, S., Young, R.G., Ryan, K.G., 2012. Within mat variability in anatoxin a and homoanatoxin a production among benthic Phormidium (cyanobacteria) strains. Toxins 4, 900912. Zamyadi, A., MacLeod, S.L., Fan, Y., McQuaid, N., Dorner, S., Sauvé, S., Prévost, M., 2012. Toxic cyanobacterial breakthrough and accumulation in a drinking water plant: a monitoring and treatment challenge. Water Res. 46, 15111523. 